\title{
MÚSICA FÍLMICA NARRATIVA A RELAÇÃO ENTRE MÚSICA E IMAGEM NA “TRILOGIA DOS DÓLARES" DE SERGIO LEONE
}

MARINA LA ROCCA CÓSER 
MÚSICA FÍLMICA NARRATIVA A RELAÇÃO ENTRE MÚSICA E IMAGEM NA "TRILOGIA DOS DÓLARES" DE SERGIO LEONE

Resumo: Por meio do presente trabalho, analisa-se a relação entre música e imagem na "Trilogia dos Dólares" de Sergio Leone, com música de Ennio Morricone. A partir de uma análise minuciosa de sequências chave de cada um dos filmes, importantes segmentos narrativos são confrontados a fim de estudar como a música interage com a imagem, produzindo sentido e criando significado junto ao espectador durante toda a trilogia.

Palavras chave: música narrativa; música para filme; Sergio Leone; Ennio Morricone

MÚSICA FÍLMICA NARRATIVA LA RELACIÓN ENTRE MÚSICA Y IMAGEN EN LA "TRILOGÍA DEL DÓLAR» DE SERGIO LEONE

Resumen: En este trabajo se analiza la relación entre música y imagen en la "Trilogía del Dólar" de Sergio Leone, con músicas de Ennio Morricone. A partir de un análisis estructural, desmembrando secuencias importantes de cada una de las películas, este trabajo compara importantes segmentos narrativos buscando mostrar cómo la música interactúa con la imagen, produciendo sentido y creando significado para el espectador a lo largo de toda la trilogía.

Palabras clave: música narrativa; música para filmes; Sergio Leone; Ennio Morricone

NARRATIVE FILM MUSIC THE RELATIONSHIP BETWEEN MUSIC AND IMAGE AT SERGIO LEONE'S "DOLLARS TRILOGY”

Abstract: Through this article is analyzed the relationship between music and image at Sergio Leone's "Dollars Trilogy", with Ennio Morricone's music. From a structural analysis, dismembering key sequences of each one of the three films, important film sequences are compared aiming to show how music interacts with image, producing sense and creating meaning on the spectator throughout the whole trilogy.

Keywords: narrative music; film music; Sergio Leone; Ennio Morricone 


\section{INTRODUÇÃO}

A “Trilogia dos Dólares" representa uma importante inovação linguística em relação ao universo fílmico western' seja através das imagens, do som, da edição. A colaboração entre Ennio Morricone e Sergio Leone - que ganha forma e força ao longo desses três filmes - é raiz dessas inovações linguísticas. Para Leone, cinema é espetáculo, é ficção, é narração sígnica. Cada elemento possui uma razão de ser e é, antes, carregado de signos. Isso inclui a música, que está fortemente ligada à narração.

Para estudar como se forma essa linguagem - hoje considerada o legado de Leone e Morricone ao cinema mundial - nesse trabalho, analisa-se importantes comentários musicais ${ }^{2}$ de cada um dos três primeiros filmes de Sergio Leone: "Por um Punhado de Dólares" (1964), "Por uns Dólares a Mais" (1965) e "O Bom, o Mau e o Feio" (1966). Após uma análise de linguagem e estrutura, tais comentários são colocados em confronto, de forma a encontrar correspondências de linguagem entre cada um dos três filmes, estudando e exaltando o legado destes mestres à arte cinematográfica.

Os exemplos musicais utilizados vêm acompanhados das suas respectivas fontes. Boa parte dos exemplos musicais foram escritos por João Tavares Filho exclusivamente para este trabalho, devido a não disponibilidade das mesmas no mercado.

\section{O WESTERN ITALIANO}

No final dos anos 50, o gênero western estava decadente nos EUA. Foi na Europa que encontrou a sua revitalização através do western italiano, também chamado spaghetti-western. O gênero, ao contrário do que se pensa, não foi criado por Sergio Leone, mas foi com ele que ganhou força internacionalmen-

1 Gênero artístico voltado a contar estórias que se desenvolvem principalmente em torno de 1950 no American Old West (Velho Oeste Americano). Também conhecido popularmente no cinema como "filme de cowboy", "filme de faroeste", ou, ainda, "filme de bangue-bangue".

2 Cada comentário musical corresponde a um momento significativo de narração através da música e imagem. Os comentários musicais propostos aqui representam uma parcela expressiva de cada um dos três filmes, mas não exaurem a totalidade dos comentários musicais presentes na "Trilogia dos Dólares". 
te, sendo considerado, até hoje, modelo de referência cinematográfica. "O western italiano é um fenômeno que mudou para sempre as características do cinema, não só western" (MELELLI, 2010, p. 61).

Os primeiros western italianos copiavam o estilo americano, porém com qualidade inferior. Para atrair o público de casa, diretores e atores se escondiam atrás de pseudônimos anglicizados. Dessa forma temos, em um primeiro momento, Sergio Leone como Bob Robertson e Ennio Morricone como Dan Savio. Leone, no entanto, não se interessa pelo western clássico. "O seu West é um território mítico onde heróis, com claras ascendências clássicas, jogam xadrez com a morte em um plano metafísico" (MELELLI, 2011, p. 11). É um western em que o protagonista não é o cavaleiro solitário e generoso da tradição, mas um killer cínico e mercenário, cuja maior virtude é a astúcia. “(...) se para os americanos o western é um gênero de fundação, que lembra as origens da própria nação, para o diretor romano é somente um veículo, a máscara imediatamente identificável de um cinema fortemente inovador sob o âmbito temático e de linguagem" (MELELLI, 2010, p. 34). As motivações para o western na Itália são, portanto, diferentes das motivações americanas. Conforme afirma Spinazzola:

O western italiano mostra uma sociedade na qual o único valor é constituído pela riqueza, a única unidade de medida das ações humanas consiste em maior ou menor adequação ao fim do enriquecimento pessoal. (...) O nosso western pretende representar de forma nua a mentalidade burguesa, capitalista (SPINAZZOLA, 1985, p. 340).

Os anos 60 na Itália são anos turbulentos: é época de Pier Paolo Pasolini e suas árduas críticas contra a burguesia que invade a Itália; o gênero western se encontra em declínio; a Itália acabou de vivenciar um período áureo do seu cinema, o neorealismo. Os western de Leone são, assim, filmes que convidam a sociedade a pensar, a abrir os olhos. É nesse horizonte que nasce o western italiano, onde o conceito de moral e amoral se fundem, a mentalidade é burguesa, o limite entre bom e mau é muito sutil e há uma intensa troca de papéis na sociedade.

O western italiano nasce não do mito do West americano, do mito de fundação de uma nação, mas sim do mito criado em torno a esse mito de fundação. A base italiana para filmes western não é a história do país, mas sim a história do cinema. O western é, na verdade, um pretexto, uma função narrativa. Os filmes de Leone são, assim, mais metafílmicos que históricos, pois fazem referência 
ao espetáculo, representando a história do cinema. Seus elementos base são a ironia e a violência. A morte, "presente de maneira anormal (...) vem despida da sua tragicidade e unidade de evento resolutivo para entrar na esfera do jogo do espetáculo" (BRUNETTA in MICELI, 1994, p. 102). Essa violência, porém, vem exposta com um caráter de hiper-realidade, de retrato de um período histórico sem falsificações. Conforme afirma Leone: "Se eu mato um com a 45 carregada com balas de chumbo, o faço saltar cinco metros para trás, porque essa é a verdade" (LEONE in MELELLI, 2010, p. 23). Existe, portanto, a violência, mas também a sua sátira. Pode-se dizer que essa hiperrealidade deriva do neorealismo que a Itália acabara de viver.

O western para um estrangeiro pode ter somente o caráter de uma fábula e viver em um mundo paralelo àquele real, justamente porque pertence a uma outra cultura. (...) A escola neorealística de De Sica e aquela do meu pai (Roberto Roberti), proveniente do cinema mudo onde a imagem precisava possuir uma força e autonomia, me fizeram entender que era justo se expressar com uma nova forma de linguagem, capaz de conjugar tanto a eloquência e a abstração do mudo quanto a verdade e os detalhes do neorealismo. Tudo, se possível, sem perder de vista que o cinema é, em primeiro lugar, espetáculo e que, enquanto tal, requer também uma dose de ironia (LEONE in MICELI, 1994, p. 103).

Aqui temos dois conceitos base do cinema de Leone: cinema como espetáculo e a hiperrealidade - uma realidade exagerada, a fim de evidenciá-la. "(Leone) filtra tudo com uma ironia puramente italiana, brincando com a gramática do cinema, inventando de fato o primeiríssimo plano dos duelantes, dilatando os tempos da atuação, suspendendo em uma dimensão surreal os seus heróis sem nome" (MELELLI, 2010, p. 16). Leone trabalha com a dilatação do tempo, aumentando a espera e, consequentemente, a tensão através da edição, da interpretação e da música. A tensão cresce exponencialmente, chegando ao momento dos disparos, quando essa se dissolve muito rapidamente, permitindo ao filme reconstruir a expectativa novamente. Os filmes de Sergio Leone contam, assim, com vários clímax durante o desenrolar da história, constituindo diversas unidades narrativas carregadas de tensão, que levam a um gran finale.

No western americano, assim como no poema épico ou nos contos de aventura, o evento principal, a prova qualificante ou glorificante é 
única e colocada em uma posição muito forte, ao final da estória. No western italiano, a tensão não possui um verdadeiro clímax: cada unidade narrativa está conectada a confrontos e cada uma dessas unidades produz uma carga emocional equivalente mesmo que, como nos espetáculos pirotécnicos, o gran finale contenha os movimentos mais espetaculares e a carnificina resulte mais carregada de efeitos (BRUNETTA in MELELLI, 2010, p. 64).

Durante toda a segunda metade dos anos 60, o western italiano se encontra consolidado. Entre 1964 e 1974, a Itália produziu mais de 400 filmes western. A partir de 1968, a Itália atravessa um período de instabilidade política e o espectador deixa de rir.

O western italiano, com seus pistoleiros amorais, foi consequência direta da desilusão por um milagre econômico que logo desapareceu. Nos anos 80 , marcados pelo hedonismo, será a comédia, erótica e suja, a constituir a diversão privilegiada dos espectadores da península, não mais preocupados em se defender de si mesmos (MELELLI, 2010, p. 22).

O gênero western italiano não teria feito sucesso internacionalmente se não tivesse desenvolvido um estilo inconfundível, seja do ponto de vista visual, seja do ponto de vista narrativo.

\section{LEONE E MORRICONE - A PAISAGEM SONORA}

Baseado no potencial iconográfico, o western dispensa diálogos excessivos. "Em um filme western, as pausas, os momentos de maior reflexão ou introspecção e, portanto, potencialmente estáticos, são elementos postos em função estratégica, a fim de realizar a clássica alternância entre clímax e anticlímax" (MICELI, 1994, p. 97). É essa dimensão que proporciona à música de Morricone um lugar privilegiado nos filmes de Leone.

A trilha sonora dos western italianos é um unicum em relação a qualquer outro gênero da história do cinema uma vez que, sendo os diálogos majoritariamente reduzidos a frases de efeito e com uma brevidade fulminante, a música desenvolve um papel essencial na definição psicológica das personagens, na determinação de uma atmosfera específica, na aplicação de ritmo às imagens (MELELLI, 2010, p. 53). 
Desde "Por um Punhado de Dólares" a música assume, já a partir dos créditos de abertura, uma importância fundamental, conotando a identidade e a novidade do gênero. Morricone introduz uma instrumentação moderna aos filmes, ligada à música popular contemporânea, mas também ligada à música e aos instrumentos pertencentes à realidade da tradição western. A rítmica é moderna, quase rock.

"No western italiano a música ganha mais espaço, vira protagonista, invade a imagem. (...) No western clássico podia acontecer de ocorrer um duelo final sem absolutamente nenhum comentário musical” (PEZZOTTA, 2012, p. 70). A música, portanto, funciona como elemento semântico junto à imagem. Leone, em geral, dá à música espaço para falar do psicológico das situações e Morricone usa esse espaço com maestria.

(...) a música suaviza espaço e tempo. Nas longas cenas de duelo dos filmes de Sergio Leone, em que as personagens se encontram paradas como estátuas uma em frente à outra, a música de Ennio Morricone é fundamental para tornar aceitável tal imobilização do tempo. (...) Também é verdade que o diretor inaugurou esta fórmula com referência à ópera lírica, evidenciando a música (CHION, 2001, p. 84)

Com a música emerge o que não é dito pelas personagens. Estas, porém, não são simplesmente músicas originais, mas se fundem com barulhos da cena, levando ao espectador da época uma percepção bastante perturbadora. Usam-se sons que aludam ao imaginário coletivo western, sons rudimentares, mas também instrumentos musicais e ritmos do presente, em uma tentativa de aproximar o espectador da narração. "Chicoteadas, assobios, sinos e outros efeitos sonoros se somam a notas de guitarra, trompete e berimbau de boca. Um universo musical, uma paisagem sonora que rompe com a tradição e vira marca registrada de todos os western italianos sucessivos" (MELELLI, 2010, p. 35). Nas palavras de Ennio Morricone:

Leone me confessou, anos depois, que para fazer com que Eastwood atuasse daquela maneira, o convidava a pensar uma invectiva forte voltada ao seu antagonista. Essas palavras pesadas ficavam sem ser ditas, mas Leone queria que elas queimassem dentro do ator, transformando-as em determinação. De fronte à uma direção assim, e com resultados excelentes, surgiu a necessidade, para mim, de buscar 
sons incomuns que pudessem equivaler a esses excessos de que falei. Tudo, inclusive a parte sonora, precisava parecer muito mais do que era. Por isso os sinos, o chicote, a bigorna, o argilofono, as vozes, e tantas outras coisas (MORRICONE in MELELLI, 2010, p. 54).

Em um cinema arquitetado tão minuciosamente, a edição desenvolve um papel ainda mais significativo. Já dizia Eisenstein:

Eisenstein, como grande entusiasta da edição no cinema, geralmente não admite, em momento algum, a possibilidade de uma função insignificante para a edição no cinema sonoro. Ao contrário: ele se esforça para aumentar essa função e, de algum modo, aumentar as possibilidades para a edição no cinema sonoro (...) [diz Eisenstein:] "A mim parece que o cinema sonoro pode ser usado em sua melhor maneira por diretores que reconheçam o enorme papel da edição no cinema, diretores que considerem a edição não como uma forma de colar partes separadas, mas como um fator que estabelece a independência da arte cinematográfica" (TAYLOR, 2010, p. 133).

Valendo-se de uma edição muito precisa, existem momentos bem definidos em que a música deve aparecer, e Leone sabe como usar dessa ferramenta. "É frequentemente a ausência de música durante boa parte de um filme de Leone que torna a entrada musical tão notável e dramática" (LEINBERGER, 2004, p. 13).

De modo a fazer a música falar, Morricone não aceita o método de composição para filmes utilizado em Hollywood, uma vez que esse se assemelha a um processo industrial, onde cada um possui uma função específica e não trabalham juntos: enquanto o maestro e a orquestra gravam uma música para um filme, aquele que fez o arranjo já está trabalhando em outro filme e o compositor está fazendo música para outro filme ainda. Ao contrário, Morricone acompanha o seu trabalho até o final, com a finalidade de entregar o produto que ele idealizou, proporcionando, assim, uma maior precisão em relação ao seu intuito inicial, modo a somar significativamente ao conto cinematográfico. "Em toda a história da música, nenhum compositor teve sua partitura escrita por outra pessoa. Porque isso ocorre na música para filmes?" (MORRICONE in LEINBERGER, 2004, p. 14).

Com uma forte base de música erudita, mas também uma grande veia 
de música popular, Morricone consegue criar músicas verdadeiramente particulares. "Ele tinha os meios e a oportunidade para se aventurar em um reino de música para filmes de que poucos compositores gozaram. Um reino experimental que eventualmente virou o seu legado" (LEINBERGER, 2004, p. 6). Ciente das limitações e condicionamentos sofridos por um compositor de música para filme, Morricone sempre buscou experimentar o quanto possível em suas composições. Nas palavras do maestro: “A minha reação me levou pouco a pouco a um comportamento criativo, do qual tomei consciência com o tempo" (MORRICONE, 2012, lectio magistralis). Dessa forma, Morricone escreve suas músicas para filme colocando-se entre experimentalismo e necessidade comunicacional. "A música de Morricone pode ser moderna e dissonante, mas ao mesmo tempo tonal ou modal, e ainda muito melódica, tornando-se acessível para o espectador comum" (LEINBERGER, 2004, p. 8).

Para comunicar uma mensagem, a música, como significante, deve se valer de códigos já conhecidos pelo público.

O discurso da semântica no cinema deve ser afrontado com aquilo que o público já sabe; o público não pode entender uma mensagem musical nova no cinema. Infelizmente este deve encontrar a confirmação daquilo que já sabe. (...) é absolutamente necessário um contato entre público e cinema. É necessária a tentativa e a vontade de fazer compreender (MORRICONE in MICELI, 2010, pp. 482-483).

O compositor não deve, portanto, se limitar a uma melodia evocativa, temas românticos ou de suspense. Deve comunicar junto às imagens, junto ao diretor, participando de toda a composição sonora do filme. Sergio Leone, reconhecendo a importância de um trabalho integrado entre compositor e diretor, começa a encomendar músicas ou esboços destas ainda antes de começar a rodar o filme, servindo de base para as filmagens, imergindo os atores em uma atmosfera sonora que os caracteriza - lembrando que os diálogos nesses filmes são curtos e potentes e grande parte da estória vem narrada por expressões, pequenos gestos, ou mesmo olhares. Leone e Morricone, juntos, seguiam esse sistema de trabalho e, já partir de "Por um Punhado de Dólares", Ennio Morricone vira um coautor efetivo nos filmes de Sergio Leone. 


\section{CONFRONTO}

Realizando um confronto entre os filmes da "Trilogia dos Dólares", no que diz respeito à relação entre música - ou comentário musical - e imagens, encontramos muitas recorrências, em uma espécie de linguagem que se desenvolve ulteriormente a cada filme. Todos os três são filmes western e, portanto, Morricone recorre a instrumentos diferentes, rústicos, que possam fazer referência ao caráter rudimentar da realidade western. Assim, temos nos três filmes a forte presença do assobio, de instrumentos percussivos, do violão, mas também temos a presença de alguns instrumentos insólitos, como por exemplo o berimbau de boca (de origem siciliana e, portanto, pertencente à cultura italiana). Já o uso da guitarra - timbre popular contemporâneo ao lançamento dos filmes - busca aproximar o espectador à estória contada. Não faltam, ainda, instrumentos eruditos, que se somam a essa variedade tímbrica, tornando a música épica e dramática. Através de ritmos, timbres, arranos e melodias, a música incorpora simbologias precisas que são exploradas durante os filmes.

Ennio Morricone não perde tempo para mostrar o seu arsenal de sons magníficos e cores sonoras (já a partir dos créditos de abertura de cada um dos filmes), deixando assim pouco espaço à imaginação do ouvinte. Da mesma forma, ele encontra maneiras de surpreender a audiência durante os filmes, não só com combinações incomuns de tonalidades, mas com temas rápidos em tonalidade menor; temas lentos e tristes em tonalidades maiores; mudanças expressivas de andamento; crescendos de energia musical à la Beethoven; e ocasionalmente uma pausa brusca, para que possa construir novamente o nível de entusiasmo (LEINBERGER, 2004, p. 70).

Tais variações na estrutura musical, levando os espectador aos mais altos níveis de emoção, dizem respeito também à linguagem de edição no cinema de Leone. Desde o início do filme o espectador ganha um panorama total da "realidade" fílmica e é prontamente atraído para dentro da narração.

As partituras/músicas se desenvolvem junto à narração; não são fechadas. Se adaptam às necessidades da situação narrativa. Leone é um diretor que trabalha muito com a simbologia, com o espetáculo. Da mesma forma trabalha Morricone com sua música para esses filmes. Cada elemento possui uma representação simbólica específica, o que podemos notar através das recorrências musicais entre um 
filme e outro, mas também entre músicas diferentes dentro de um mesmo filme.

\subsection{Créditos de Abertura}

“Todos (os filmes da 'Trilogia dos Dólares') tem temas extensos que acompanham créditos de abertura animados. Estes temas tendem a ser fracionados em motivos conforme o desenrolar dos filmes" (BROWN, 1994, p. 228). Tanto "Por um Punhado de Dólares" quanto "O Bom, O Mau e o Feio", iniciam com créditos de abertura acompanhados de imagens geradas através de rotoscoping 3 (Figuras 1 e 2). Essas imagens - antecipando cenas do filme - e acompanhadas de uma música representativa do universo sonoro do filme, já nos integram ao que estamos por ver. Entre esses dois filmes temos «Por uns Dólares a Mais", que usa essa técnica muito rapidamente, no primeiro e último quadro do prólogo (Figura 3). Essa diferença técnica, no entanto, não significa que “Por uns Dólares a Mais" não nos apresente elementos da estória já no início. Esse é um filme completamente baseado no mistério, onde teremos reveladas as motivações reais das personagens (principalmente de Mortimer) somente no final do filme. Este prólogo enfatiza a dimensão de mistério - não sabemos quem disparou e nem quem estava sobre o cavalo - e também a dimensão de violência e crueldade do ambiente West.

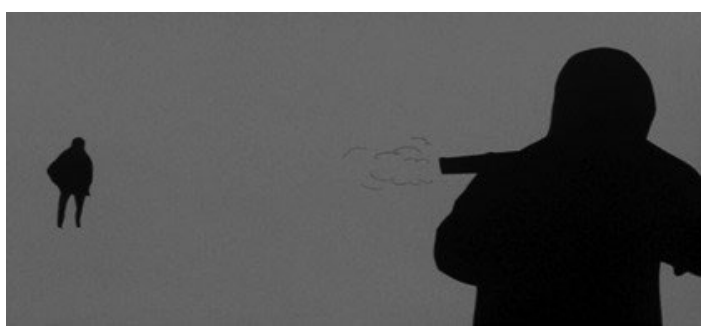

Figura 1: Rotoscope, Tema de Abertura, "Por um Punhado de Dólares"

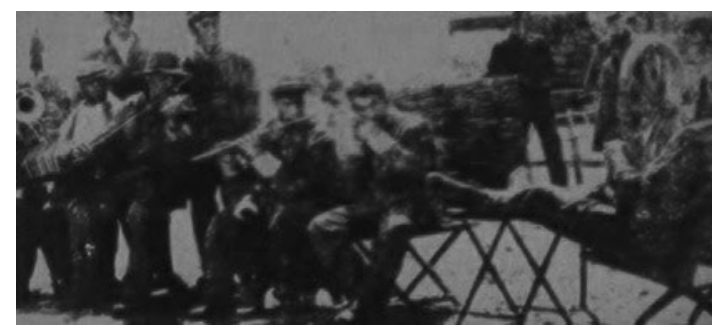

Figura 2: Rotoscope, Tema de Abertura, "O Bom, o Mau e o Feio"

3 Técnica de animação utilizada para criar um desenho animado em que figuras humanas pareçam realistas. $O$ desenhista realiza as cenas a partir de uma película filmada precedentemente. 


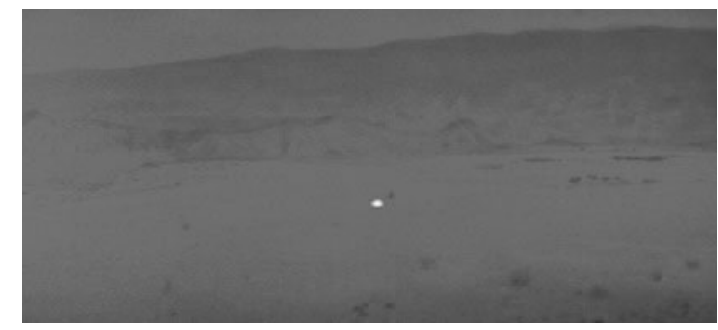

Figura 3: Rotoscope, Prólogo, "Por uns Dólares a Mais"

A música que acompanha cada uma das aberturas alude à música dos outros filmes. Como primeira característica, temos a tonalidade comum a todas: Ré menor. As músicas apresentam uma base rítmica, sempre fazendo alusão ao galope de cavalos e, portando, são todas baseadas na mesma proporção rítmica (Ex. 1). Além disso, esse ritmo reaparece em diversas músicas em cada um dos filmes, reforçando assim, a sua carga simbólica.

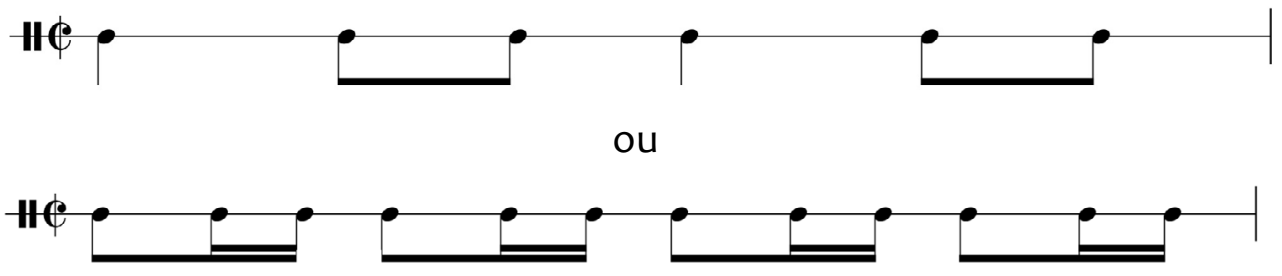

Ex. 1: Ritmo de galope (TAVARES FILHO, 2012)

Os temas musicais também são fortemente ligados. Os temas de abertura de "Por um Punhado de Dólares" (Ex. 2) e de "Por uns Dólares a Mais" (Ex. 3) começam com o mesmo intervalo: uma IV justa constituída por Lá e Ré, partindo da anacruse para chegar ao Ré no tempo forte do compasso. A partir daí cada tema desenvolve a sua melodia, mas ambas culminam a primeira frase melódica em um Ré ( $8^{\circ}$ compasso de "Por um Punhado de Dólares" e $6^{\circ}$ compasso de "Por Alguns Dólares a Mais") para, só depois, desenvolver suas variações. "O propósito do Tema de Abertura (em "Por um Punhado de Dólares") é claro: marcar a tonalidade de Ré menor dórico ${ }^{4}$, prolongá-la com movimento de escala e chegar ao Ré" (KAUSALIK, 2008, p. 28). Ao mesmo tempo, em "Por uns Dólares a Mais", Ennio Morricone:

4 Escala menor com o VI grau maior 
brinca com a expectativa do ouvinte, evitando o som do violão, característico no Tema de Abertura de "Por um Punhado de Dólares". Tudo nesta melodia é mais conciso que na sua antecessora. No lugar de quatro compassos de introdução, "Por uns Dólares a Mais" só possui um. A idéia musical base dura dois compassos, ao contrário do primeiro filme, em que a ideia base tinha aproximadamente cinco compassos (KAUSALIK, 2008, p. 37).

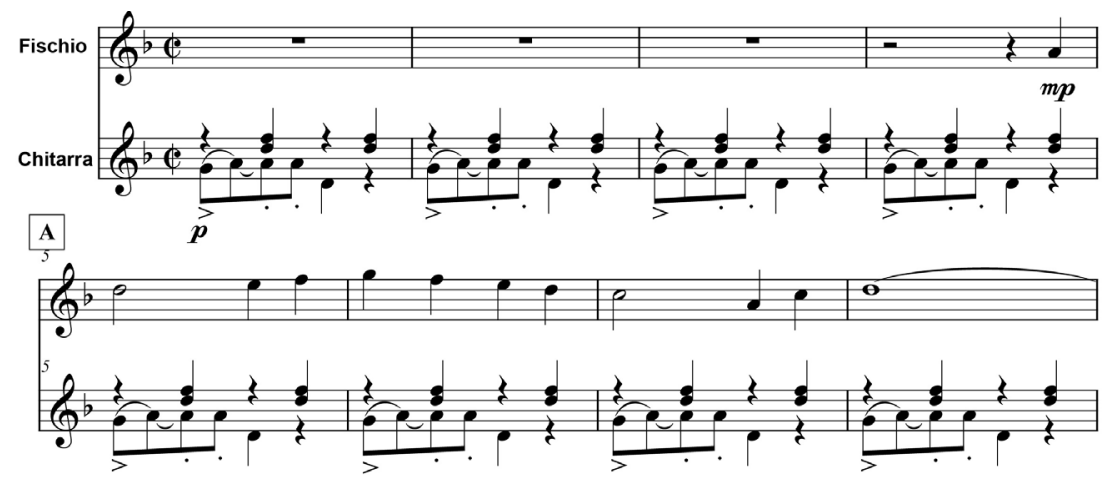

Ex. 2: Compassos 1 a 8, Tema de Abertura, "Por um Punhado de Dólares" (TAVARES FILHO, 2012)

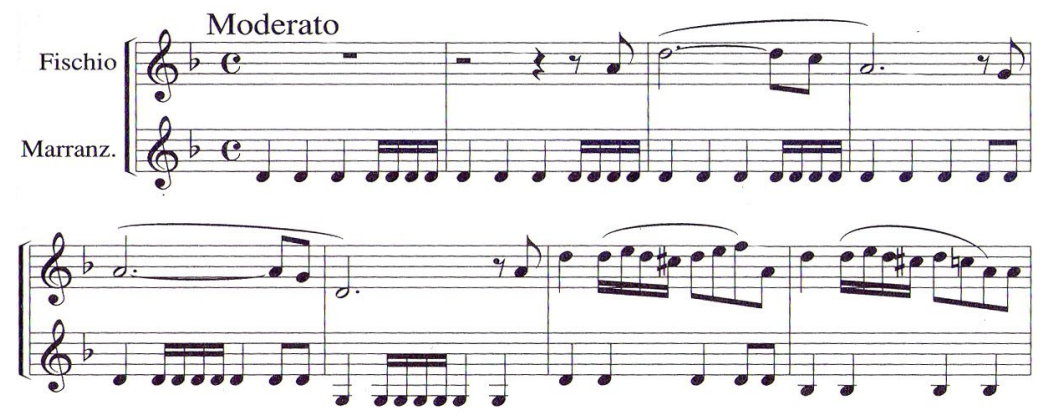

Ex. 3: Compassos 1 a 8, Tema de Abertura, "Por uns Dólares a Mais" (MICELI, 1994, p. 125)

À primeira vista, o discurso é outro no que diz respeito ao Tema de Abertura de "O Bom, o Mau e o Feio" (ex. 4). Aqui o tema da melodia, ou melhor, o primeiro tema melódico se refere ao motivo que marca cada protagonista do filme. Segue, no entanto, a brincar com o intervalo de IV justa dos temas anteriores. Uma segunda seção do Tema de Abertura nos leva a um tema muito semelhante aos temas dos dois filme anteriores, não mais brincando sobre o intervalo La-Ré, mas desenvolvendo uma verdadeira melodia (Ex. 5). 


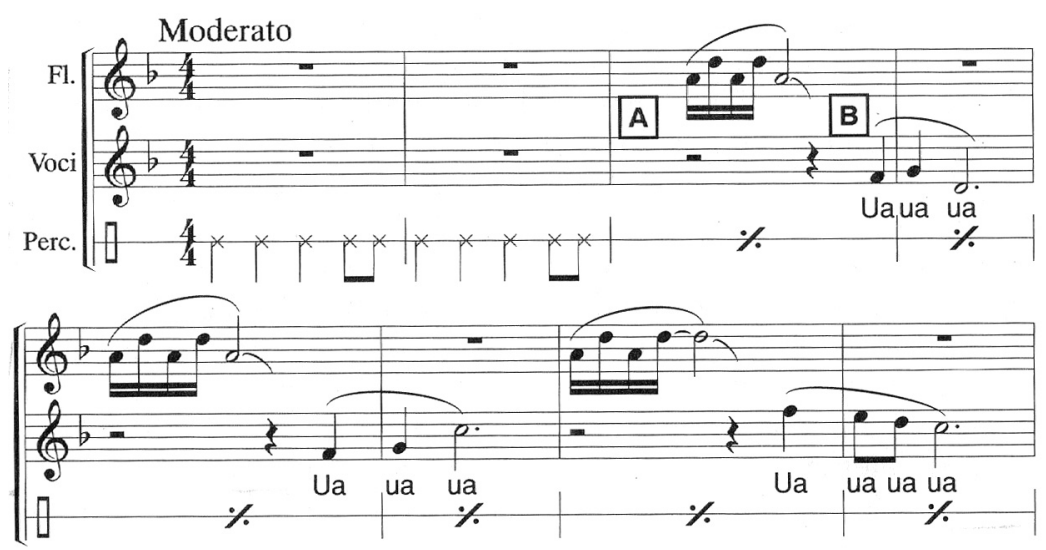

Ex. 4: Compassos 1 a 8, Tema de Abertura, “O Bom, o Mau e o Feio” (MICELI, 1994, p. 132)

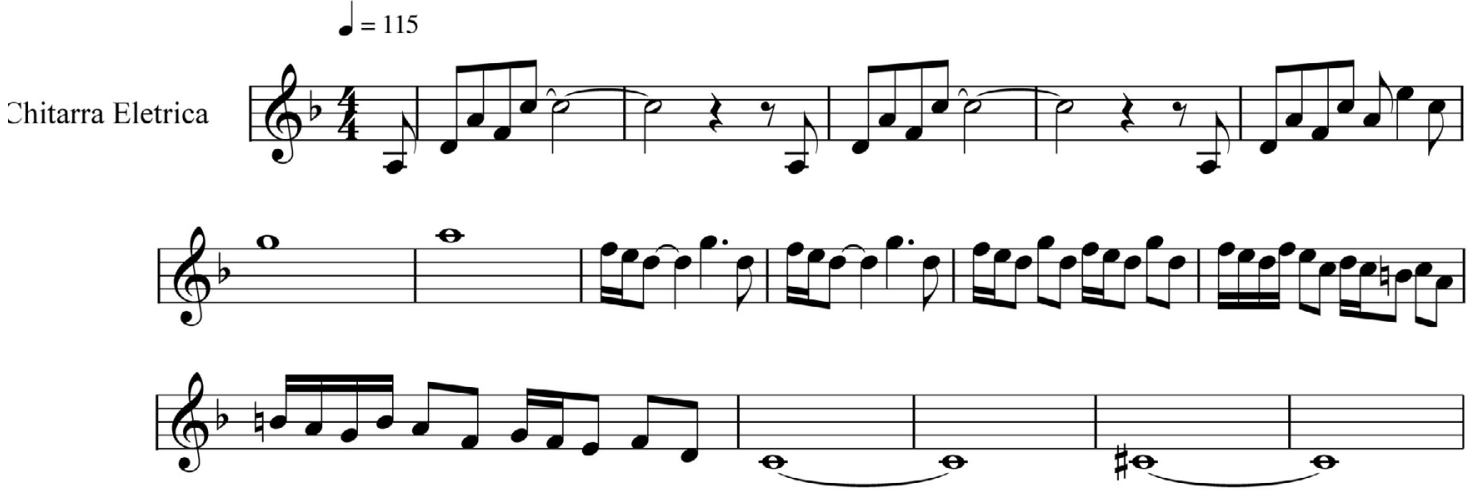

Ex. 5: Melodia guitarra, Tema de Abertura, “O Bom, o Mau e o Feio” (TAVARES FILHO, 2012)

Todos os três temas de abertura apresentam o motivo melódico que se refere ao protagonista. No caso de "Por um Punhado de Dólares", a partir do compasso 29 o tema da flauta (Ex. 6), que marca Joe (Clint Eastwood), é repetido a cada dois compassos por quase todo o restante da música. Em "Por uns Dólares a Mais", novamente é a flauta a marcar o protagonista Clint Eastwood (Monco). Dessa vez, entra a partir da anacruse do $15^{\circ}$ compasso (Ex. 7), sendo repetido, também aqui, a cada dois compassos. Já em "O Bom, o Mau e o Feio", como acabamos de ver, o motivo que marca os protagonistas - aqui três - vem logo apresentado, transformando-se em tema. De fato, ainda antes de começar oficialmente a música, ouvimos o motivo (Ex. 8) repetir três vezes, cada repetição com um instrumento diferente, junto à imagem de um cavaleiro em rotoscoping, sem, porém, identificá-lo (vide 4.2). A primeira variação é feita com a flauta, enquanto que a segunda apresenta o "grito do coiote" e a terceira, a ocarina. Um espectador familiarizado com os dois filmes anteriores, ao ouvir esse motivo curto e preciso, em Ré menor tocado com flauta, espera já que esse seja o elemento 
musical para identificar Clint Eastwood. De fato, a música começa com uma série de repetições desse motivo, sempre com a flauta, e logo vemos o crédito com o nome de Clint Eastwood (Figura 4) - confirmando a ligação.

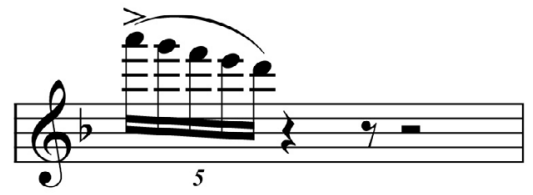

Ex. 6: Motivo da flauta - Clint Eastwood, "Por um Punhado de Dólares” (MICELI, 1994, p. 114)

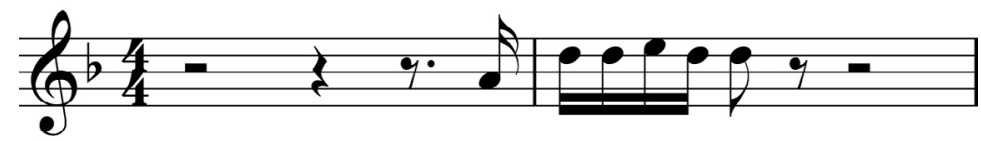

Ex. 7: Motivo da flauta - Clint Eastwood, “Por uns Dólares a Mais" (MICELI, 1994, p. 125)

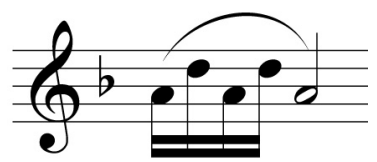

Ex. 8: Motivo da flauta - Clint Eastwood, "O Bom, o Mau e o Feio” (TAVARES FILHO, 2012)
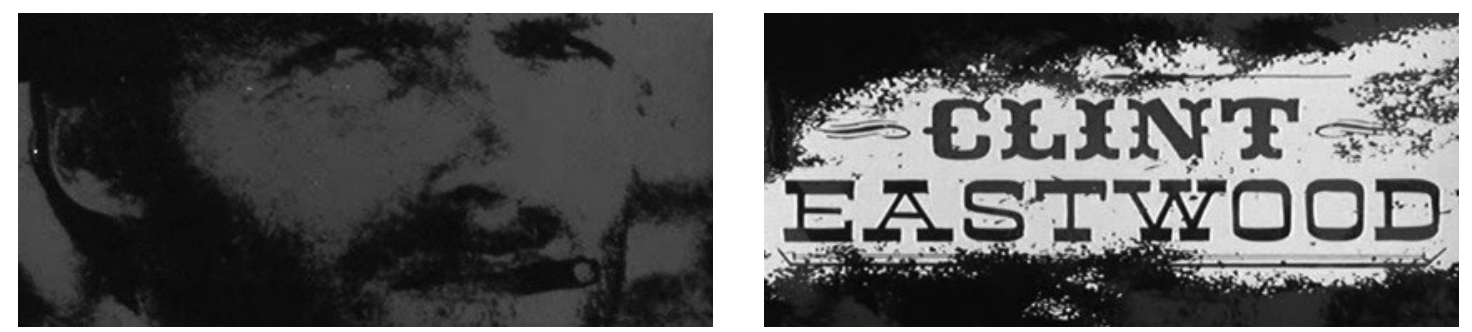

Figura 4: Clint Eastwood, Tema de Abertura

É evidente também uma ligação verbal entre os filmes. Acompanhando a estória de "Por um Punhado de Dólares", sabemos que o motivo da flauta que representa Joe o caracteriza como uma personagem atenta, azougue. Em "Por uns Dólares a Mais", antes de vermos a personagem de Clint Eastwood (que apresenta o mesmo visual do protagonista do filme anterior), o coronel Mortimer é avisado que "um cara azougue" está procurando o mesmo homem que ele. Logo depois vemos pela primeira vez, e de costas, Clint Eastwood, que chega. Agora, seu nome é Monco, mas suas características já nos são confirmadas serem as mesmas do Joe de "Por um Punhado de Dólares" seja através das características musicais, seja através das suas vestes.

Os três temas de abertura, após essa exposição primeiramente rítmica e, 
posteriormente, melódica com um orgânico ainda leve, crescem em orgânico durante o seu desenrolar, sempre buscando evidenciar sons da realidade western. Este tema, em cada um dos três filmes será posteriormente fragmentado, originando diversas variações, que adquirem características dramáticas e simbólicas conforme a instrumentação, o andamento, o orgânico, as dinâmicas, o ritmo e timbres e retornará depois, na sua versão original, nos momentos representativos de retomada da aventura e, com ainda mais força nas cenas de aventura com cavalos, com o orgânico completo e ainda um coro masculino.

A ideia de $c u e^{5}$ praticamente não existe nas músicas de Morricone para Sergio Leone, assim como em muitos de seus outros trabalhos. Isso não quer dizer que as músicas se apresentem ao ouvinte/espectador com um tema completamente desenvolvido: Leone, assim como Godard, é capaz de isolar pequenos fragmentos - às vezes até mesmo uma única nota - do seu material musical cru. Mas Morricone, assim como Prokofiev para Eisenstein ou Antoin Duhaeml para Godard, teve a felicidade de escrever temas que tenham lógica musical ao mesmo tempo em que apresentam grande quantidade de efeito cinemático (...) Os temas desenvolvidos de Morricone são permitidos tocar inteiros em diversos momentos, criando momentos com um lirismo cine-musical que mais de um crítico descreveu como operático (BROWN, 1994, p. 228)

A música no cinema de Sergio Leone não apresenta uma forma rígida, permitindo a sua reapresentação nas mais diversas formas, de modo a se adaptar à necessidade narrativa. Assim, temas musicais são constantemente reapresentados com variações tímbricas, rítmicas ou mesmo de andamento, elevando o potencial dramático da cena ao máximo. Os comentários musicais ganham o espaço de tempo necessário para o seu desenvolvimento, apresentando momentos de lirismo em que as cenas adquirem status de ópera, de drama encenado acompanhado de música. A narração vira, portanto, puramente imagem (ação) e música.

\subsection{A Tematização das Personagens: O Bom, o Mau e o Feio}

As primeiras cinco notas (Ex. 9) do Tema de Abertura de "O Bom, o Mau e o Feio" formam a base de toda a trilha sonora do filme.

5 o termo music cue tem origem no teatro e diz respeito à inserção musical como um sinal para um ator desenvolver determinada ação 


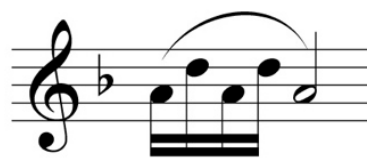

Ex. 9: compasso 1, Tema de Abertura, “O Bom, o Mau e o Feio” (TAVARES FILHO, 2012)

Esse motivo é logo repetido três vezes, cada vez porém com uma instrumentação diferente. Cada versão representa um dos três protagonistas, seguindo a ordem de aparição no filme: flauta para Biondo - o Bom; vozes masculinas, uma oitava abaixo, para Tuco - o Feio; e ocarina, duas oitavas abaixo, para Sentenza - o Mau. Essas três distinções sonoras são usadas por Morricone e Leone durante todo o filme, informando o espectador sobre qual protagonista está por agir. Mesmo sendo cada protagonista diferente do outro, seus papéis no decorrer do filme se trocam facilmente e perdemos a noção de limite entre bom e mau, entre suas características. A música também nos comunica isso, apresentando as personagens com um mesmo tema musical, que varia em oitava e em timbre. "A música de Ennio Morricone para 'O Bom, o Mau e o Feio' é nada menos que um marco na evolução estilística da música para filme, não só para o gênero western, mas para todo o cinema" (LEINBERGER, 2004, p. XVIII).

Antes que o Tema de Abertura comece oficialmente, vemos a imagem de três homens a cavalo, um após o outro (Figura 5), sincronizada com cada uma das três variações do mesmo motivo (Ex. 10).

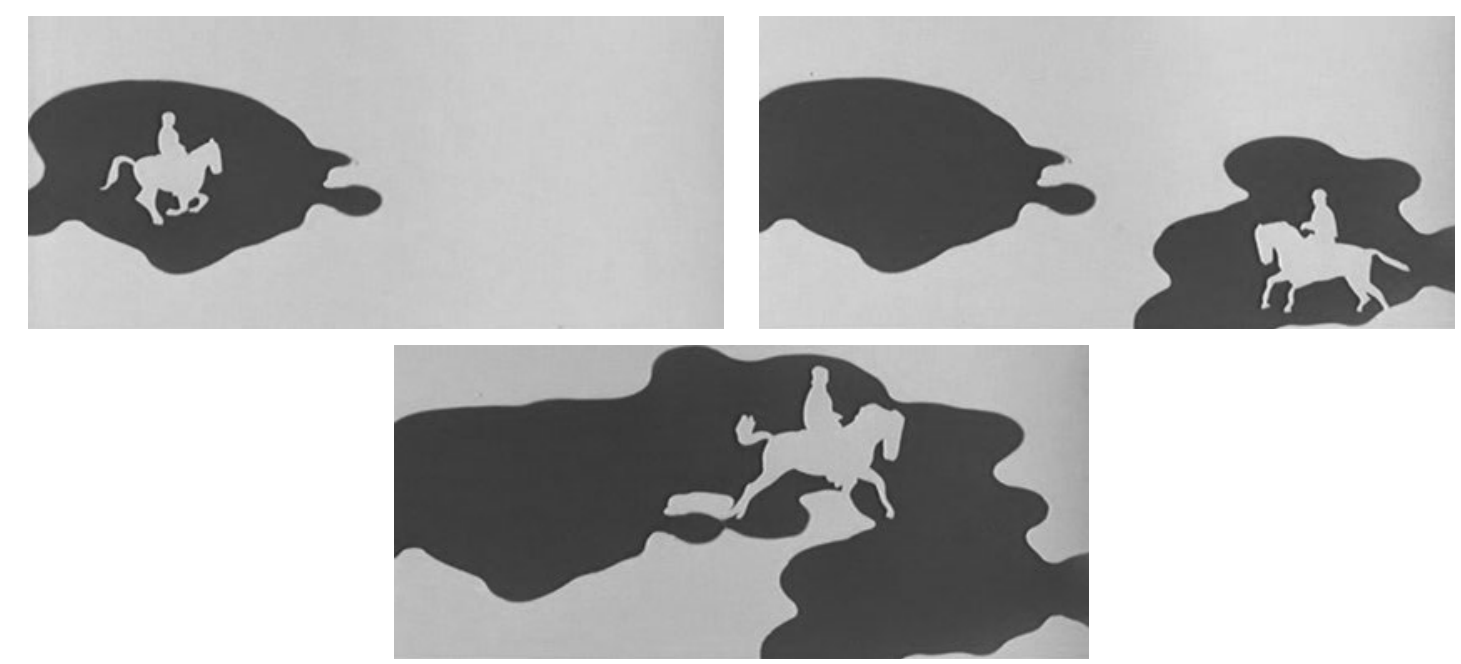

Figura 5: os três homens a cavalo - diferentes mas semelhantes 


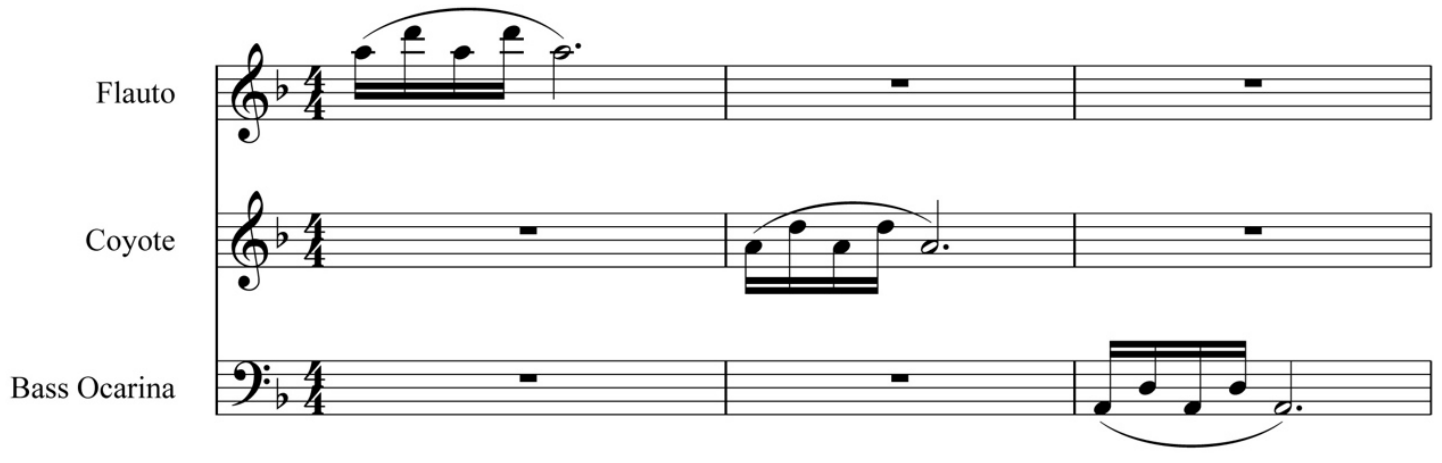

Ex. 10: Diferenciação Tema, “O Bom, o Mau e o Feio” (TAVARES FILHO, 2012)

Dessa forma, o primeiro elemento que o filme nos apresenta é essa diferenciação sutil entre três cavaleiros diferentes mas semelhantes em muitos aspectos. Não existindo uma diferenciação evidente entre os cavaleiros, é o timbre, em um primeiro momento, a diferenciá-los. Da mesma forma, durante o filme o conceito de bom e de mau se perde e se mistura em todos os protagonistas. Todos são bons, são maus e são feios - característica antecipada pela música através da utilização da mesma melodia, com diferença de timbre.

\subsection{A Loucura}

A loucura é um elemento que não está presente no primeiro filme, mas nos outros dois ganha uma atenção especial e uma caracterização bem específica. Em "Por uns Dólares a Mais", temos a personagem Índio, chefe de uma quadrilha que é liberado da prisão por seus companheiros. Quando liberado, a sua loucura começa já a se evidenciar. Um desses momentos é quando ele bate em uma porta e atira quando alguém se aproxima para abrí-la. Os momentos mais fortes, no entanto, são: o da sua risada, quando está saindo da prisão (Figura 9) - é uma risada louca, grandiosa e forte; e quando se vinga daquele que o colocou na prisão - até mesmo seus movimentos e seu jeito de falar aludem à dimensão da loucura. A sua música tema é a do carillon (Ex. 11), tocada pelo seu relógio de bolso. A cada duelo seu, Índio coloca o carillon a tocar, marcando o momento dos disparos. Essa melodia é forte e explicitamente ligada ao seu caráter. Executada por uma celesta, a melodia ganha sons ambíguos, dissonantes, durante a qual fica difícil definir uma única nota.

Em “O Bom, o Mau e o Feio", temos uma referência explícita a essa dimen- 
são da loucura. Mesmo que Tuco pareça uma personagem normal, quando o vemos explicar a Biondo o seu objetivo no deserto - objetivo que, na realidade, é loucura, uma vez que pode matar Biondo, mas também a si próprio - nos é mostrado como louco. Reforçando essa dimensão de loucura, temos uma melodia que se refere à melodia do carillon do filme anterior: uma melodia quase doce, mas carregada de dúvidas, de mistério - de harmônicos (Ex. 12). A risada crescente de Tuco (Figura 10) também se encarrega de reforçar essa dimensão de loucura fortemente simbólica.

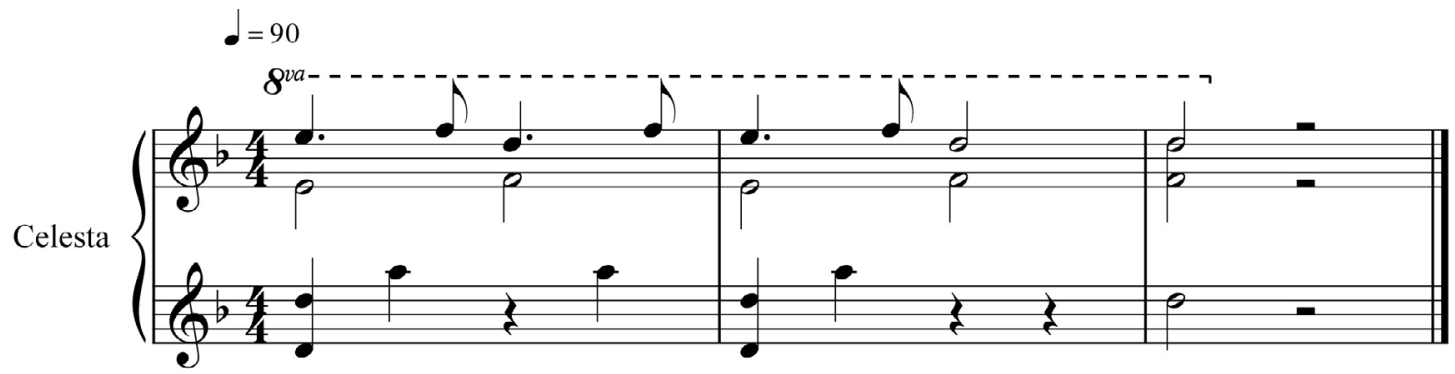

Ex. 11: Melodia carillon, La resa dei conti, “Por uns Dólares a Mais” (TAVARES FILHO, 2012)

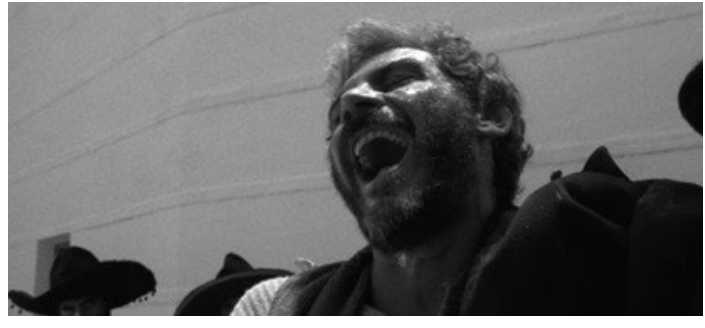

Figura 6: Risada Índio, "Por uns Dólares a Mais"
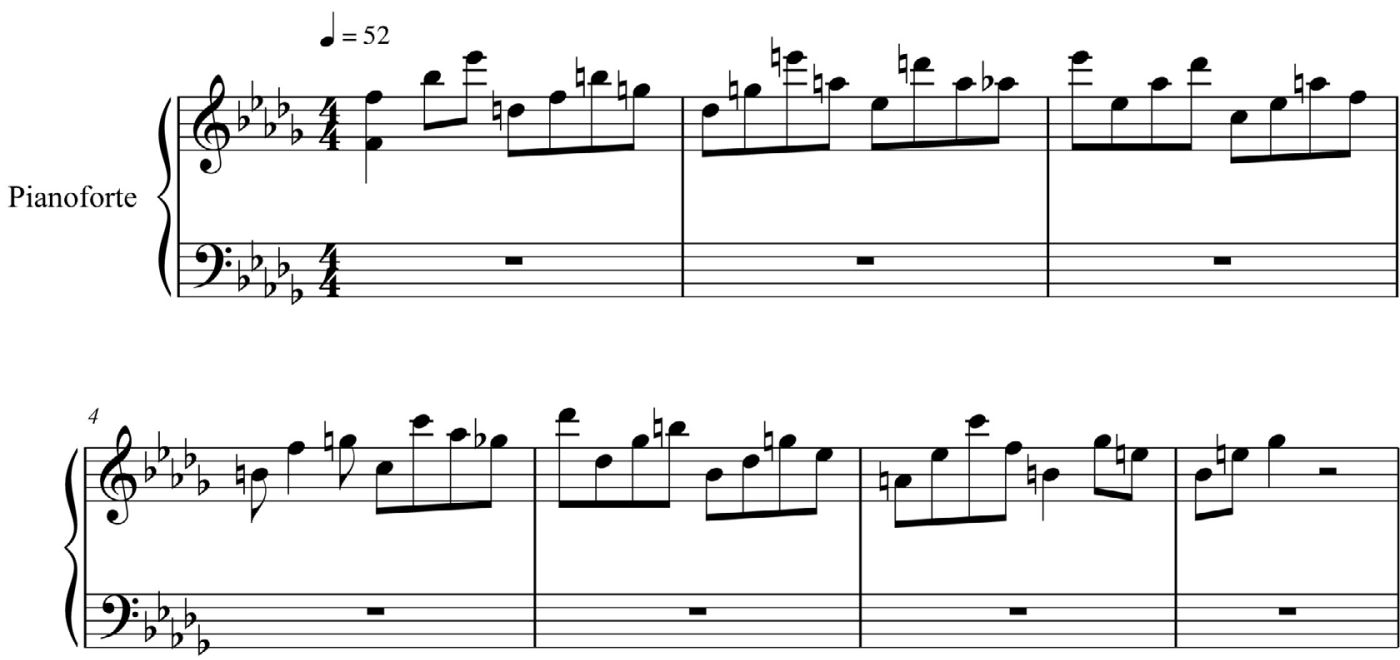

Ex. 12: Melodia piano, Il deserto, “O Bom, o Mau e o Feio” (TAVARES FILHO, 2012) 

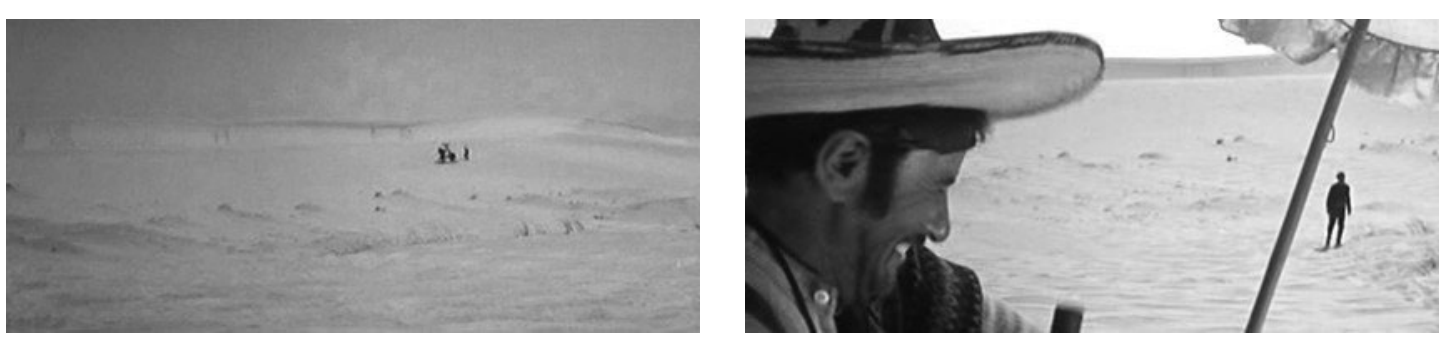

Figura 7: Risada Tuco, "O Bom, o Mau e o Feio"

Apesar de parecer um exemplo simples de ligação entre os filmes, fica muito claro o conceito de construção simbólica entre imagem e som entre um filme e outro, de forma a apresentar uma ideia bastante específica.

\subsection{Os Confrontos Finais}

Pode-se dizer que, para os confrontos finais, Morricone reserva uma fórmula específica, em que o trompete - que em todos os finais simboliza o triunfo, a salvação - vira instrumento protagonista. Não se trata, no entanto, de um triunfo qualquer, mas sim da personagem representada por Clint Eastwood.

Em uma espécie de crescendo de um filme ao próximo, a melodia do trompete ganha maior energia. "O solo realizado em 'O Bom, o Mau e o Feio' é o mais intenso e empolgante de todos, subindo até a gama de sons mais brilhante do instrumento" (LEINBERGER, 2004, p. 105). Não é apenas o trompete a representar esse crescendo dramático. Em uma espécie de acúmulo energético, Morricone aplica, a cada filme, elementos dos capítulos anteriores pertencentes à trilogia.

Dessa forma, temos em "Por um Punhado de Dólares", o final mais simples, até porque é o primeiro capítulo da trilogia e não pode, portanto, ter acumulado informações de outros capítulos. A música que acompanha o duelo final deste filme é, na verdade, uma reapresentação do tema do filme que, anteriormente, era realizado pelo oboé (Ex.13) e aqui vem ao som do trompete (Ex. 14). O caráter da melodia muda, ganhando mais floreios e recorrendo a uma frase em staccato ao invés de legato, tornando-se mais triunfal. Retomando o tema do filme, a música começa já carregada pela dimensão emocional, uma vez que acumulou informações/dramatizações durante todo o filme. 


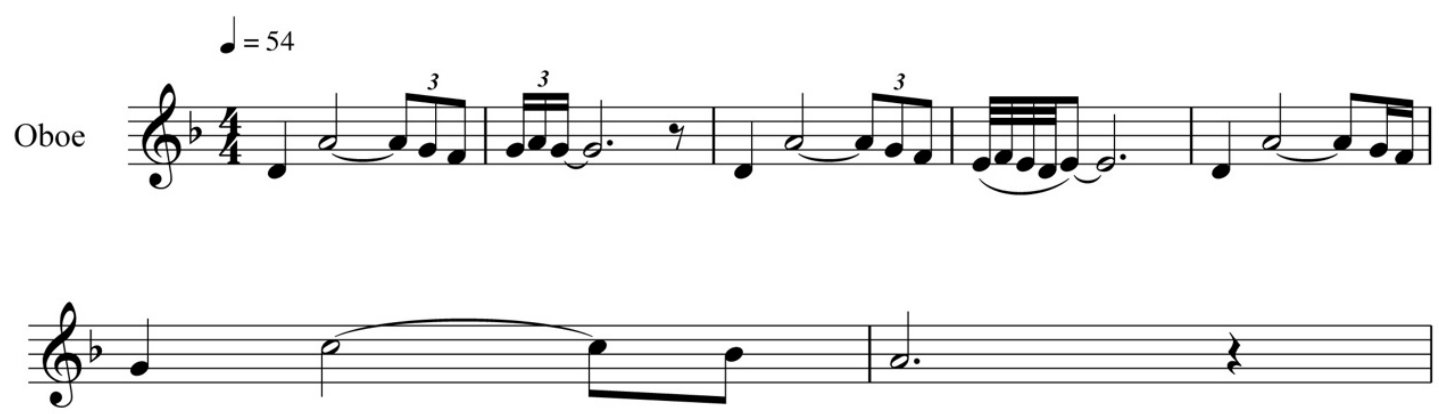

Ex. 13: Oboé, Tema, “Por um Punhado de Dólares” (TAVARES FILHO, 2012)

Tromba
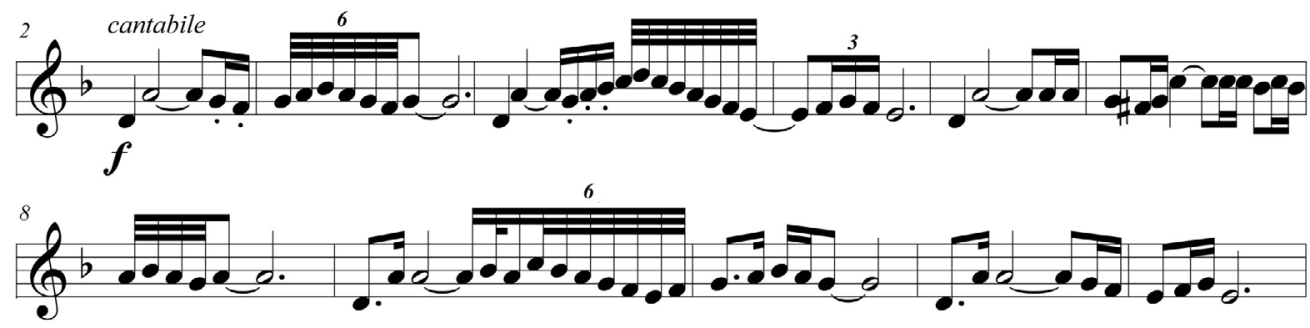

Ex. 14: Trompete compassos 2 a 12, Tema, "Por um Punhado de Dólares” (TAVARES FILHO, 2012)

Já em “Por uns Dólares a Mais", essa carga emocional cumulativa vem expressa através da retomada de temas do próprio filme - a melodia do carillon - mas também pelo acréscimo de elementos que nos remetem ao filme anterior. Assim sendo, a base rítmica desta música é a mesma do tema de "Por um Punhado de Dólares" (ex. 15 e 16). O ataque da base rítmica coincide com o momento em que Monco se move em direção a Mortimer, após ter interferido no duelo e estar assumindo o controle da situação. Não se trata mais de Mortimer e Índio, mas de Monco (Clint Eastwood).

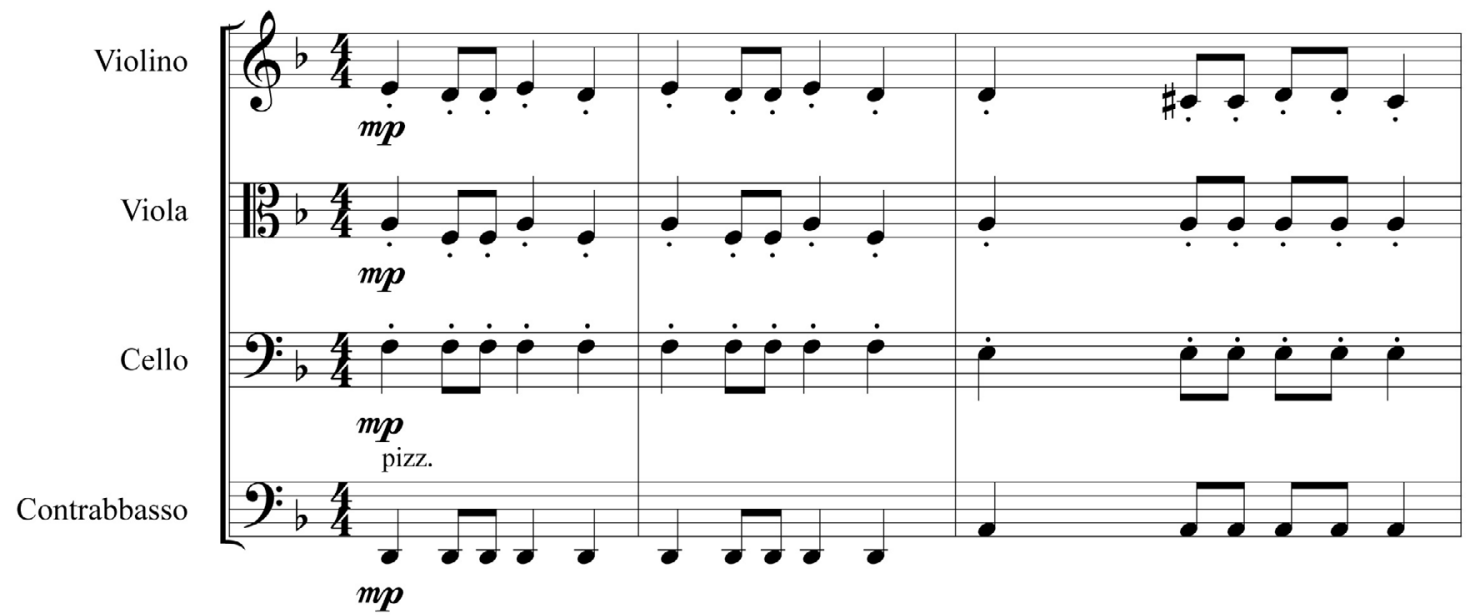

Ex. 15: Base rítmica, Tema, “Por um Punhado de Dólares” (TAVARES FILHO, 2012) 


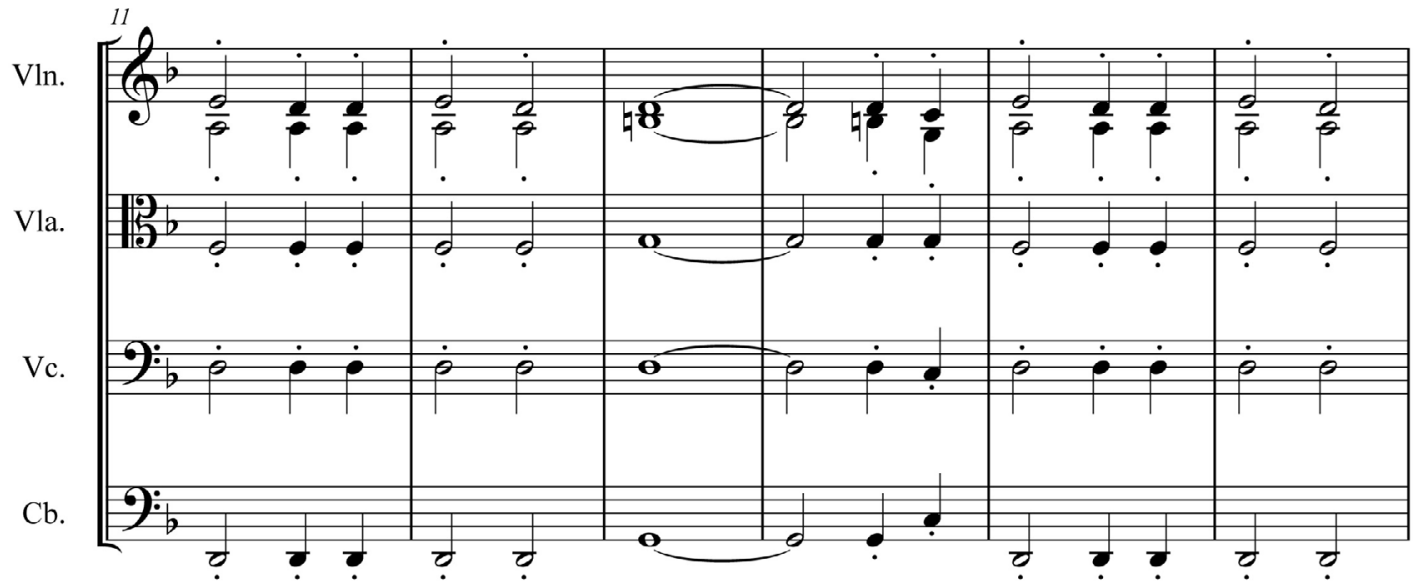

Ex. 16: Base rítmica, La resa dei conti, “Por uns Dólares a Mais” (TAVARES FILHO, 2012)

Após 2'36" de introdução, já carregada de informação e dramaticidade, entra o trompete (Ex.17), que coincide com o momento em que os três "duelantes" se posicionam para o confronto.

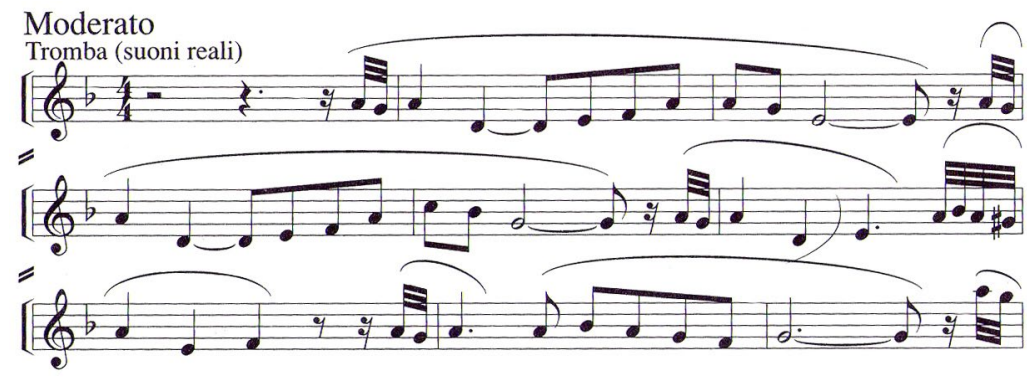

Ex. 17: Melodia trompete, La resa dei conti, “Por uns Dólares a Mais” (MICELI, 1994, p. 125)

Em “O Bom, o Mau e o Feio", temos o mesmo mecanismo de carga emocional, mas também de informação no que diz respeito à música. Esse é o terceiro e último capítulo da trilogia e sua música é, evidentemente, mais enérgica do que as músicas finais dos capítulos anteriores. Após 1'35" de tensão musical, entra o solo do trompete, novamente ligado ao momento em que os três se posicionam para o "duelo". A melodia do trompete é exposta (Ex. 18) para depois, com um corte abrupto, dar espaço ao silêncio - ou melhor, sons ambientes - por 10", quando entra novamente a música, pronta a reconstruir a tensão e dramaticidade da cena. Nesse momento, o ataque musical se dá com a melodia que alude ao carillon de "Por uns Dólares a Mais". Essa melodia pouco a pouco se alterna com elementos sonoros de "O Bom, o Mau e o Feio", culminando com o solo do 
trompete. De "Por um Punhado de Dólares" temos ainda a base rítmica, porém não tão evidente quanto no confronto final do segundo capítulo.

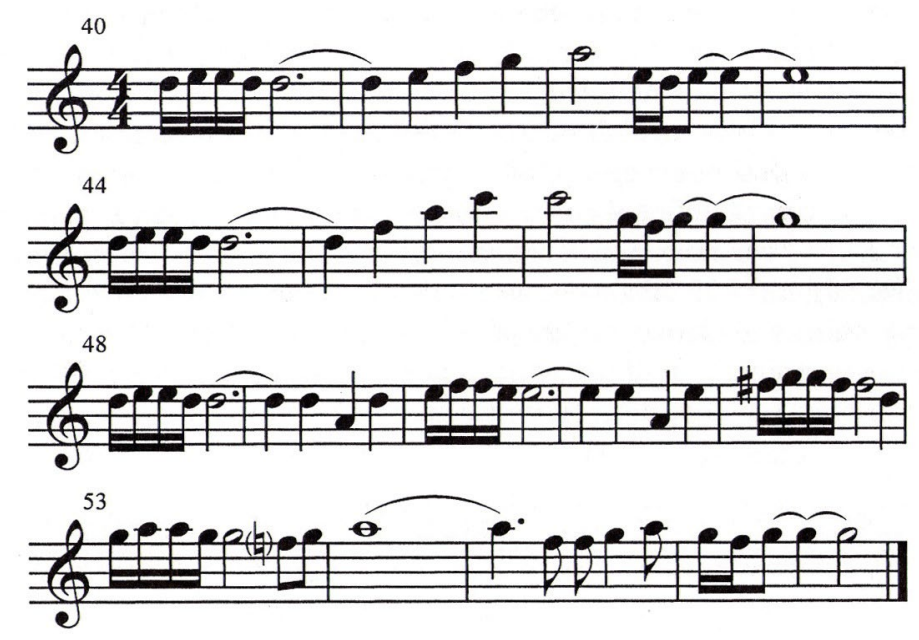

Ex. 18: Trompete, Il triello, “O Bom, o Mau e o Feio" (LEINBERGER, 2004, p. 105)

A ligação, portanto, entre um confronto final e outro é muito evidente, assim como também é muito clara a ligação entre as personagens de Clint Eastwood durante os três episódios da trilogia. Estes confrontos finais se remetem um ao outro não somente por estrutura, mas também por estilo e linguagem, através da edição, dos solos mariachi, dos elementos musicais.

\section{CONSIDERAÇÕES FINAIS}

Para Leone, a música era uma parte integrante dos filmes e não apenas um comentário e isso vem evidenciado não somente na presente trilogia, mas em todo o seu cinema. As músicas de Morricone para cada um desses filmes faz referência à trilogia como um todo, criando uma espécie de unicum sonoro. Os instrumentos também se remetem, assim como pequenos trechos de uma música vem inseridos em outra, ligando as três estórias. A tal propósito, a música de Morricone é constituída de microsegmentos que podem ser apresentados separadamente, contribuindo ao processo de significação. Leone usa e abusa dessa propriedade, atribuindo à música um nível simbólico e narrativo que a cada filme se torna mais elaborado.

Com essas novas sonoridades e conceitos, Morricone concedeu não somente aos filmes western, mas a toda a música para filmes, uma nova linguagem. 
"Hollywood logo reconheceu as significativas contribuições de Morricone aos westerns (...) No início da década seguinte, Morricone fora chamado a compor músicas também para filmes de Hollywood" (LEINBERGER, 2004, p. 7). A linguagem musical de Morricone, rompendo com o padrão - industrial - de Hollywood e trabalhando, ao mesmo tempo, com música erudita e popular, levou ao cinema uma nova sonoridade, destinada a mudar os paradigmas da música para filme.

Leone, por usa vez, também deixou ao cinema um grande legado, com seus primeiríssimo planos, seus tempos dilatados e diálogos escassos. Podemos falar de cinema puro, onde os responsáveis pela produção de sentido junto ao espectador são imagem e som, e os diálogos, unicamente informativos, são, por sua vez, musicais. Dessa forma, a música, o som, as imagens e os diálogos são, cada um, carregados de informações e cada um possui o seu momento de falar. O cinema, portanto, vira lírico, vira obra de arte.

\section{REFERÊNCIAS}

BROWN, R. Overtones and Undertones: Reading Film Music. Los Angeles: University of California Press, 1994.

CHION, M. L'Audiovizione Suono e Immagine nel Cinema. Torino: Lindau, s.r.l, 2001.

KAUSALIK, E. A fistful of drama: musical form in the dollars trilogy. Masters of music, Graduate College of Bowling Green State University, USA, 2008.

LEINBERGER, C. Ennio Morricone's the Good, the Bad and the Ugly - a film score guide. Lanham: Sacrecrow Press, Inc., 2004.

MELELLI, F. Sergio Leone e il Western all'Italiana, tra Mito e Storia. Perugia: Morlacchi Editore, 2010.

MICELI, S. Morricone, La Musica, il Cinema. Milano: Mucchi Editore, 1994.

MICELI, S. Musica e Cinema nella Cultura del Novecento. Roma: Bulzoni Editore, 2010.

MORRICONE E. Lectio magistralis, Auditorium Conciliazione, Roma 01/06/2012.

PEZZOTTA, A. Il western italiano, Milano: Il Castoro, 2012.

SPINAZZOLA, V. Cinema e pubblico: lo spettacolo filmico in Italia 1945-1965, Roma: Bulzoni Editore, 1985.

TAYLOR, R. Sergei Eisenstein: Writings, 1922-1934, New York: I. B. Tauris, 2010. 


\section{Partituras:}

TAVARES FILHO, J. Partituras arranjadas por João Tavares Filho para este trabalho.

LEINBERGER, C. Ennio Morricone's the Good, the Bad and the Ugly - a film score guide. Lanham: Sacrecrow Press, Inc., 2004.

MICELI, S. Morricone, La Musica, il Cinema. Milano: Mucchi Editore, 1994.

\section{Filmes:}

Por um Punhado de Dólares (Per un Pugno di Dollari), de Sergio Leone, 1964, 99 min.

Por uns Dólares a Mais (Per Qualche Dollaro in Più), de Sergio Leone, 1965, 132 min.

O Bom, o Mau e o Feio (II Buono, il Brutto, il Cattivo), de Sergio Leone, 1966, 161 min.

RECEBIDO EM: 01/03/2013

ACEITO PARA PUBLICAÇÃO: 26/06/2013

\section{Marina La Rocca Cóser}

Mestre em "Forme e Tecniche dello Spettacolo:Cinema" pela Universidade La Sapienza de Roma. Graduada em Comunicação Social: Publicidade e Propaganda pela Universidade Federal de Santa Maria. Atualmente cursa uma especialização em Digital Audio / Video Editing também na Universidade La Sapienza de Roma. 
